Navigating Academia as a Working-Class Academic

Crew, Teresa

Journal of Working-Class Studies

DOI:

https://doi.org/10.13001/jwcs.v6i2

Published: 25/12/2021

Publisher's PDF, also known as Version of record

Cyswllt i'r cyhoeddiad / Link to publication

Dyfyniad o'r fersiwn a gyhoeddwyd / Citation for published version (APA):

Crew, T. (2021). Navigating Academia as a Working-Class Academic. Journal of Working-Class Studies, 6(2), 50-64. https://doi.org/10.13001/jwcs.v6i2

\footnotetext{
Hawliau Cyffredinol / General rights

Copyright and moral rights for the publications made accessible in the public portal are retained by the authors and/or other copyright owners and it is a condition of accessing publications that users recognise and abide by the legal requirements associated with these rights.

- Users may download and print one copy of any publication from the public portal for the purpose of private study or research.

- You may not further distribute the material or use it for any profit-making activity or commercial gain

- You may freely distribute the URL identifying the publication in the public portal ?
}

Take down policy

If you believe that this document breaches copyright please contact us providing details, and we will remove access to the work immediately and investigate your claim. 


\title{
Navigating Academia as a Working-Class Academic
}

\author{
Teresa Crew, Bangor University
}

\begin{abstract}
Despite an increasing focus on the impact of class in higher education, less has been said about the experiences of those working-class people who navigate from student to scholar. In the largest interview study to date, conducted in the United Kingdom, this paper draws upon extensive qualitative interview data with ninety working-class academics. This article highlights the hostile encounters faced by these academics but also illuminates the forms of capital and the assets they bring to academia. The article suggests how we can move forward before providing a reminder that the working class should not be viewed by their supposed deficits (real or imaginary).
\end{abstract}

\section{Keywords}

Working-class, academic, microaggressions, hostile

\section{Introduction}

Class lurks in every nook and cranny of society. Taking higher education as one example, a report from the National Education Opportunity Network (Neon) ${ }^{1}$ found that those who were in receipt of free school meals are the least likely of all groups, after people of Gypsy Traveller heritage, to study at university. If they do attend university, they are less likely to enrol at prestigious institutions (Atherton \& Mazhari, 2019). While those that traverse from nontraditional student to scholar provide a compelling example of widening access, we are less likely to hear about their experiences. Perhaps as Attfield (2007) critically comments, there is a presumption that entry into academia is a 'ticket out of the working classes' (p. 33). But the material conditions of one's social heritage has a lasting impact on one's identity, especially in a hierarchical institution like academia (Crew, 2020). The classic texts on these 'Strangers in Paradise' (Ryan \& Sackrey, 1984), suggest that the academy is not a welcoming environment, as the different worlds working-class academics (WCA) inhabit are often in conflict with each other. For instance, Dews and Law (1995) highlight there is a sense of being 'neither here nor there', so much so that 'the working-class academic can never fully move in' (p. 130). Patricia Hill Collins (1986), described herself as 'outsider within' due to her standpoint as a Black female professor. While Case (2017) acknowledged her ethnic and heteronormative privileges, she referred to her middle-class colleagues social and financial capital, as being obvious 'mark[s] of difference' (LeCourt \& Napaleone, 2011: 83).

\footnotetext{
${ }^{1} \mathrm{NEON}$ is a professional organisation in the United Kingdom that supports those involved in widening access to higher education.
} 
Contemporary literature addresses key themes such as academic casualisation, intersections of identity (Michell et al., 2015) and how an institution influences one's experience (Binns, 2019). Lubrano (2005) felt that his working-class family 'don't like who I've become' (p.232), but then on the other hand he found he did not like socialising with colleagues. Warnock (2016) offers a detailed analysis of the lived experiences of WCA based on material published over the span of thirty-two years (p.28), noting that WCA often have survivor guilt, whereby they feel guilty for the financial and social benefits they have accrued. In addition, Warnock (2016) revealed microaggressions to be typical for working-class students and scholars. A survey by Haney (2016) of the Canadian professoriate found that 40 per cent of participants reported experiencing classist language (p.150). The literature on WCA serves as a reminder that 'class distinctions do not die; they merely learn new ways of expressing themselves.' (Hoggart, 1989).

\section{Researching working-class academics}

The genesis of this study was grounded in my many interactions with students, who often remarked that I am 'not like other lecturers'. I instinctively knew what these students meant by this as I reside in the same social housing estate I lived in prior to attending university, and as I travel in by bus, I often talk to students outside of university. Speaking to colleagues, both male and female, who were the 'first in their family' to become an academic, they too had received similar comments from their students. This intrigued me and led to this research study, its main aim being to understand more about the lived experiences of WCA, such as the difficulties they may face and the skills that they might bring into the academy. Respondents were recruited in three ways: via the social media platform Twitter; at various academic conferences within the Social Sciences, and referrals from previous respondents. The selection criteria required that respondents should self-define as a 'working-class academic' and currently/have worked in the last six months at a UK university.

This article draws upon data gathered from ninety working-class academics ${ }^{2}$, the largest interview study conducted with WCA in the UK, to date. Respondents were recruited from twenty different subject areas, although most (two thirds, n.60) were from an Arts and Humanities background. The convenient sampling methods used meant that it would be less likely that I would recruit WCA from Science, Technology, Engineering and Maths (STEM) ${ }^{3}$. Empirical research talks of the effectiveness of social media recruitment (see Gelinas et al,. 2017) however, users of social media are not representative of the general population (Ruths \& Jurgen, 2014), and this mode of recruitment tends to generate responses from people with similar characteristics, with similar things to say on the given topic ${ }^{4}$. Comparable numbers of interviewees from 'redbrick', 'Post 1992' and 'Traditional' institutions took part, but less so from Oxbridge universities ${ }^{5}$. Most interviewees were either 'early career' or 'mid-career', with

\footnotetext{
${ }^{2}$ I originally intended the research to be a small scale study, comparable to Ryan and Sackrey (1984) who collected data from twenty-four college professors, with roots in the working class, or Mahony and Zmroczek (1998) who included the autoethnographies of fifteen female working-class academics. However, there was such interest in this study that I interviewed 90 respondents. I stopped data collection after an eighteen month period after a natural break in recruitment as I would never have been able to analyse and write up the findings. I am now in the process of interviewing WCA from STEM subjects.

${ }^{3}$ As such I am currently conducting additional research on WCA from STEM subjects.

${ }^{4}$ Thank you to the reviewers of this article for their useful and supportive comments in relation to this issue.

${ }^{5}$ Redbrick Universities in the UK are a group of institutions founded in 6 major British industrial cities during the 19th century. There were originally engineering or science colleges. These universities got their 'redbrick' label from the style of brickwork common at the time. See: https://www.theuniguide.co.uk/advice/choosing-acourse/what-is-a-red-brick-university-list-of-red-brick-universities
} 
fewer self-defining as being 'late career'. Just over half were on permanent contracts, with the rest experiencing some level of precarity. Two thirds were female, which is typical for many research studies, except for clinical trials where women are underrepresented (National Institute for Health Research, 2020). Fourteen per cent identified as being Black, Asian, Minority Ethnic (BAME) and six per cent reported that they had a disability. Seven out of ten respondents resided in English institutions, with approximately half having worked at more than one institution across the UK. Interviews were carried out via online video conferencing, with a small number being conducted in person at either the respondent's workplace or a café. Interviewees were given a copy of the information sheet, consent form and the interview schedule so they had full details of the study.

\section{Theoretical framework.}

Bourdieu's trilogy of 'thinking tools' - habitus, field and capital have informed this study. The field is defined as a set of relationships which can be intellectual, cultural, educational, etc. (Navarro 2006). The field (in this case, academia) is the arena in which an individual and their social biography (habitus) interacts. One's habitus influences an individual's ability to generate and accumulate capital (or power) (Bourdieu 1986). A field is a competitive space with its own rules and patterns of behavior (Bourdieu 1984), those whose habitus and capital are desired will be privileged. In academia, it is a middle-class habitus (and forms of capital) that dominate and monopolise this field.

Tara Yosso (2005) contests Bourdieu's view on the value of 'elite' 'knowledge' since this perpetuates deficit models of thinking. Yosso introduced the concept of community cultural wealth which includes six forms of capital held by members of marginalised communities: Linguistic: social skills attained through communication in more than one language/style. Social: community resources. Familial: cultural knowledge that carry a sense of community history. Aspirational: maintaining hope despite barriers. Navigational: skills from manoeuvring social institutions. Resistance: knowledge and skills fostered through oppositional behaviour that challenges inequality (pp. 77-80).

\section{Lived experience}

Lisa McKenzie's 2015 article in Times Higher Education ${ }^{6}$ about being a working-class female academic, was an early inspiration for this study as it offered a way of conceptualising my identity in comparison to other academics. My family biography is a mixture of working in manual employment, long-term illness, claiming benefits alongside an 'aspirational' working class habitus $^{7}$ (Lawler, 2005, p. 434). I enjoyed school as I was a voracious reader, but my

The UK's two oldest universities, Oxford (est. 1096) and Cambridge (est. 1209) are the most revered, elite institutions of higher education in the UK. The term 'Oxbridge' was used in a Thackeray's Pendennis in 1849 and is often used to denote these two elite institutions within the UK.

In 1992 the UK government formally abolished the binary divide between universities and polytechnics to establish a unitary system of higher education for UK. The 1992 Further and Higher Education Act granted thirty five polytechnics full university status. See: https://wonkhe.com/blogs/analysis-25-years-on-the-higherand-further-education-act-1992/. Traditional (pre 1992) Universities typically are more research-intensive, while post-1992 universities, the former polytechnics, may be less research-intensive, and tend to focus on vocational courses.

See an article by Boliver (2015) for a more detailed discussion https://dro.dur.ac.uk/14978/1/14978.pdf

${ }^{6} \mathrm{https}$ ://www.timeshighereducation.com/lisa-mckenzie-who-would-be-working-class-woman-academia

${ }^{7}$ I'm not overly fond of the term aspirational as it is typically used to divide the disadvantaged into

'skivers' and 'strivers' (Williams, 2013, para one), terms which are popular in UK political discourse to 
parents' divorce meant I was displaced, often moving between houses and cities. My education suffered and I began to truant regularly, before leaving school with no qualifications. My parents encouraged me but lacked the knowledge to talk to me about further education, or support unfamiliar career choices, thus waitressing and retail were my only career options. I enjoyed working with the general public but was intellectually unfulfilled. Inspired by a simple desire to be able to read the 'posh' broadsheet newspapers, I enrolled on a Criminology degree with my local, traditional university. Imposter syndrome was rife but I fell back in love with learning. I approached my degree like a job and graduated with a first. I worked in local government alongside doing postgraduate study. I also worked as a teaching assistant, then a lecturer in my institution, on a precarious contract for four years before becoming a senior lecturer. This sounds like a simple transition, but it wasn't as easy as that. Academic casualisation is rife in academia so these were difficult years filled with self-doubt and worry. Academics on fixed term contracts are 'cheap, flexible and disposable, hence their appeal to universities' (Zheng, 2018 cited in Leathwood \& Read, 2020, p.3). Permanent contracts are like gold dust in academia so I still pinch myself now that I am fortunate enough to teach and research subjects that fascinate me, although feeling 'lucky' is typical of an academic 'like me' (Mahony \& Zmroczek, 1997). I have been fortunate in my institution as my colleagues are kind and supportive, but apart from engaging with other WCA, outside of my institution can be a toxic environment. Returning to McKenzie (2015), her words 'It's hard work defending ourselves...against those who judge us, look down on us, sneer and laugh at us' (para. 7) send a chill down my spine because I know exactly what she means. This study, inspired by a desire to understand more about the atypical academic, uncovered a variety of experiences.

\section{Not Fitting In}

For around eight in ten respondents, navigating academia as a WCA could be difficult. Skeggs (1997), when discussing her own experiences as a working-class woman in academia, talked of 'not getting it right' (p. 130-131). This sense of alienation (Warnock, 2016), and not belonging in the world of academia with its 'distant accents and cultural conventions' (Shukie, 2020, para 2) is typical for WCAs. Throughout my interviews the same theme reoccurred: I feel I don't 'fit in'. [Anna, a lecturer in Health Sciences at a redbrick institution]. As one's social history is displayed by aspects of their hexis (the physical embodiment of habitus) (Jenkins 2000), I noted respondents mentioned their accent, clothes, and even sense of humour as areas where they did not fit in.

\section{The 'Wrong' Accent}

The way we speak reveals our class positioning by its very utterance. Where bourgeois language is 'formal', working-class language, influenced by material deprivation, is perceived to be 'common' (Bourdieu and Wacquant 1992, p. 60). The Social Mobility Commission (2015) found that working-class candidates were often unable to secure employment in elite professions such as law or banking as informal poshness tests can exclude working-class candidates from such professional occupations (Ashley et al., 2015). Research by the Chartered

\footnotetext{
describe those who are hardworking, and those who are feckless. Such labels mean there is little sympathy for those who are disadvantaged, as they are perceived as not trying hard enough, it ignores that many people are born playing catch up in the game of life.

${ }^{8}$ The Social Mobility Commission is UK, independent statutory body (an organisation created by an Act of Parliament). They are responsible for carrying out and publishing research in relation to social mobility and providing advice to ministers (at their request) on how to improve social mobility in England.

https://www.gov.uk/government/organisations/social-mobility-commission
} 
Institute of Personnel and Development $(2006)^{9}$ found that three quarters (76 per cent) of employers discriminated against applicants because of their accents. My respondents felt stigmatised for their vernacular, particularly 'Welsh' or 'northern accents ${ }^{10}$ ':

'I presented at the top scientific conference. An audience member puts up her hand and says: 'I'm finding it very hard to follow you as you are talking in a regional manner'. Upset I mentioned it to my supervisor. Rather than be sympathetic he asked if I could tone it down.' [Polly, a lecturer in Medical Sciences at a redbrick institution]

'I moved for a Lectureship, and on the first day two colleagues advised me that I may want to 'work on' my 'strong' Welsh accent if I intended to teach.' [Catrin, a lecturer in Community Health, at a redbrick institution]

Coogan (2019, para.8) in an article for the Times Higher Education suggests 'ingrained linguistic habits' can mark 'us' as being inferior. Yet my respondents noted that a regional accent can actually be an advantage, with students reportedly feeling more comfortable with lecturers who sounded like them [Polly, a lecturer in Medical Sciences at a redbrick institution]. Tbis is mentioned by in Hastie (2021) who talks of being approachable, speaking in 'his normal accent and dressing more casually' (p39-40). In relation to my own respondents, Belinda, a lecturer in Social Policy at a redbrick institution, talked of how perceived class diversity, demonstrated by having lecturers with regional accents, can have recruitment advantages and as such may be examples of what Yosso (2005) describes as cultural language resources, or linguistic capital.

\section{The 'Wrong Sense of Humour'}

Humour is an essential factor in social relationships, and for over half of my respondents, a cultural marker of class distinction:

'If I joke about, they tell me not to put myself down, but it's my humour.' [Emma, a teaching assistant in Health Studies at a post 1992 institution]

This type of humour, often used to relax others at one's own expense, was often misunderstood, with passing comments being taken literally. Humour can also be a characteristic of the 'most effective teachers' (James 2004, p. 94). Ted, a lecturer in Media Studies from a post 1992 institution expands on this talking of how he used my sense of humour with students, it...lets them feel included. Ant, a teaching associate in Social Sciences at a Russell Group institution used humour so that his students would know that I'm not a stuffy lecturer. He found that his students instantly relaxed with him. Tina, a lecturer in Secondary and Post Compulsory Education at a post 1992 institution found that using humour meant that students were more likely to join in with class activities. However, like Azizinezhad and Hashemi (2011), a small number of respondents reported that their colleagues saw their humour in the classroom as being an example of poor class conduct [Jamie, a lecturer in History at a traditional institution]. Respondents reported muting their humour to more easily navigate academia.

\footnotetext{
${ }^{9}$ A registered Charity established to promote the art and science of the management and development of people for public benefit. https://www.cipd.co.uk/

10 'Northern refers to having an accent derived from living in the north of England.
} 


\section{The Wrong 'Clothing'}

Clothing conveys meanings beyond the clothes e.g. a police uniform conveys to us immediately what the wearer's occupation is. Respondents would refer to the traditional image of an academic as being a tweed jacket with patches on the elbows (an image that excludes women). A visible sign of working-class respectability is a smart suit or dress.

'If I am teaching, or in work in general, I would dress in a skirt suit. Nothing too formal, but something smart and tidy. I always look over dressed by comparison when I look at my middle class colleagues, The women tend to wear a cardigan with a dress. Something much more casual.' [Emma, a teaching assistant in Health Studies at a post 1992 institution]

Emma, a teaching assistant in Health Studies at a post 1992 institution found that whenever she wore 'smart' clothes for work, she would be 'stared at'. It's like I'm wearing the wrong clothes, the wrong jewellery. Unpicking these extracts, they depict examples of female WCA not knowing 'the rules of the game', i.e when to wear casual clothes, and when a smarter attire would be required [Jamie, a lecturer in history at a traditional Institution]. For female academics, dressing 'too smart' may be linked with the more glamourous, 'hyper-heterosexual' forms of femininity associated with working-class women, whereas instead they should be seeking a more understated, 'acceptable', type of femininity of middle-class women referred to in Skeggs (1997). The latter femininity being a form of symbolic capital. Whereas for male academics, the right way to dress appeared to be linked with their age. For 'more mature' lecturers such as Nick, a senior lecturer in Film Studies at a redbrick institution, he reported being taken to task by 'management' when he did not wear suits or a shirt and tie. While for younger men such as Neil, a lecturer in Sociology at a traditional institution, flowery shirts and smart jeans were the preferred wardrobe, informal, but not a lazy informal, a 'studied informality' alluded to by Friedman \& Laurison, 2016, p. 149).

\section{Hostile encounters}

But the 'problem' was more than just aspects of their presentation. Experiences of behaviour otherwise known as microaggressions was rife throughout my interview data. A term coined by Pierce (1970) to describe subtle (whether intentional or unintentional), derogatory, or negative slights (Sue et al. 2007) is something often seen to be directed toward stigmatized communities (Lilienfeld, 2017). 'Subtle' is an inappropriate descriptor as the examples given here are rather crude. Microaggressions for Bourdieu (2001) are examples of symbolic violence, a imperceptible violence, even to its victims. Microaggressions include discriminatory actions such as racism, sexism or classism. Lilienfeld (2017) suggests these interactions may be callous rather than malicious, although Deb, a teaching fellow in Health Sciences at a post 1992 institution, said it's like a dripping tap. These hostile encounters were a common ingredient of professional life for my respondents.

The most visible form of microaggressions are microassaults (Sue, 2010), deliberate, and conscious, verbal and nonverbal acts, done with the intention to hurt or to discriminate. Due to the Equality Act 2010, a UK Act of Parliament that makes such overt acts discriminatory, they were the least common form of microaggression (Dovidio 2001), although as 'class' status is not a protected characteristic it is 'easier' to be overtly classist. Interview data revealed that microassaults tended to be experienced by men. Frank, a Lecturer in Geography, at a Russell Group institution recounted a microaggression he experienced at a formal dinner: 
'I was at a conference dinner, really nice...old building, a fancy affair and some posh cow said 'Oh um, have you ever been in a place like this before?'...I thought...you can either be rude... or I could just make a joke out of it, so I said only to sweep chimneys because they don't let my lot in here.'

Stefan, a researcher in broad subjects at various institutions, recounted a number of negative interactions. Stefan's extract is a difficult read, but important as we often hear little about the microaggressions faced by men. Stefan describes introducing himself at a conference and having his offer of a handshake and polite conversation ignored. During his presentation, $\mathrm{Dr}$ $\mathrm{X}$, a female academic called into question the validity of his research. When later attending Dr X's talk, Stefan picks up the story:

'I have made it my practice that when I am the sole male attendee I sit...furthest away from the speaker...I was horrified, shaken, and shocked, when in her talk Dr X referred to the 'paedophile in the corner', stared at me and made a hand gesture towards me. I glanced around and the chair of the session was looking directly at me in shock - her jaw had literally dropped. I am still affected by Dr X's actions - someone I was completely unaware of and had never met before.'

Stefan's interaction appears to be influenced by his presumed privileged identity as a white man. Yet while men as a category may appear to dominate aspects of society, this is not the case for working-class men in elite spaces. A blanket understanding of privilege, ignores that there are 'multiple marginalisation and inequalities for some, and multiple privileges and equalities for others' (Hearn, 2015, p. 56).

Respondents also reported microinsults i.e demeaning behaviours which convey a hidden insulting message to the recipient. Interviews with respondents of colour revealed that their promotions would trigger envy amongst their colleagues:

'A colleague was very interested in my promotion... she probed my credentials and expressed views on meritocratic hiring practices - the implication being that promotions were only handed out to Black guys.' [Theo, a Politics research fellow at a Russell Group institution].

The literature would likely describe these incidents as being unintentional slights, but my respondents felt these were examples of outright bigotry and racism. Microinsults are particularly problematic as they reduce the individual to a stereotype. Over half (n.46) of respondents discussed hearing the word 'chav' in relation to students 'from the exact background I am from' [Sophie, a teaching assistant in Biological Sciences at a redbrick institution]. 'Chavs' are the '21st-century grotesque' (Morad, 2012, p.672), an offensive caricature of the working class, that describes them as racist hooligans, or alcoholics, and in terms of women, as being sexually available (Jones, 2011). Amy, a teaching fellow in English at a Russell Group institution noted:

'A colleague consistently described his research respondents as chavs. I looked shocked, but it seemed to trigger a 'memory' in him, and he said, oh I'm sorry, you come from that area too? I was shocked how easily he related me to the word chav.'. 
Microinsults demean a person's heritage, identity or race, but perpetrators of microinsults appear unaware of the insulting implications of their behaviour i.e Amy suggested her colleague wasn't aware that 'chav' was a term of abuse for the white working class. But when she tried talking to him, he was unwilling to discuss the implications of his language.

Gabriel and Tate (2017) noted that racial microaggressions are an invisible feature of the Black scholar's experience in academia. Rollock (2019) interviewed 20 of the 25 Black female Professors in the UK and found they had experienced a culture of explicit and passive bullying, along with racial stereotyping and microaggressions. Racial microaggressions were particularly common to all but a small number of interviewees of colour. From being asked to show staff identity cards when entering university buildings with a white member of staff (who was not asked to show their identification), to receiving sexualized comments in academic feedback from students: my teaching doesn't get commented on ... but my physicality does. [Nicole, a Business Studies lecturer in a post 1992 institution]. Respondents of colour such as Theo and Nicole were often told they were articulate, but Theo countered what they meant was I am very articulate for a Black guy. A survey of $240 \mathrm{BME}$ staff and students by the Guardian newspaper found racism in universities is widespread and tolerated. As one respondent in the Guardian survey said: 'the message is clear: assimilate and shut up' (cited in Weale et al. 2019).

\section{Navigating university ${ }^{11}$}

When asked about what they offered academia, three quarters of interviewees (n.67) referred to the pastoral care they provided, that they perceived went above and beyond that of the typical personal tutor. This is not to say that traditional academics do not provide good quality pastoral care, but the WCA experience of inhabiting 'two distinct cultures' (Bridges 2017, p. 70) as well as navigating unsupportive environments, meant that respondents were particularly adept in helping non-traditional students. Yosso (2005) refers to this as 'navigational capital'. For instance, Lynn, a graduate teaching assistant in Mathematics at a post 1992 institution held free, monthly information, advice and guidance (IAG) sessions at a local community centre. She helped students write personal statements or with their choice of degree. Tim, a Lecturer in Social Sciences at a Russell Group Institution, of Afro-Caribbean heritage mentioned an experience he had at an open day:

'I asked him was he ok...He, the potential student, said — I'm alright, I'm working out if this is 'me'. I told him I felt the same at first. That seemed to put him at ease so... [w]e talked about why he felt like this. He said-They are posh and white mate. I laughed and said that —yeah I got [it], but... it needed people like him so that it isn't always posh and white.' (Crew, 2020: 102).

Axes of inequality are so intrinsically entwined that they reinforce one another and as such cannot be disentangled (Crenshaw, 1989). Tim, who is a visible presence of class and ethnicity, demonstrates the importance of 'seeing' class in tandem with, rather than distinct from, other aspects of our identity (e.g., ethnicity, gender, etc).

\footnotetext{
${ }^{11}$ A striking feature of the interviews was how difficult it was for respondents to give examples of what WCA offer to academia. While it is likely to be an example of how the sample was skewed towards people who had experienced difficulties in their academic trajectory, I also observed that interviewees would often compare themselves negatively in relation to the traditional academic - the influence of the deficit discourse perhaps? This is something I am currently researching.
} 
Joy, a Senior Lecturer in Social Sciences at a Russell Group institution, provided an overt way of supporting working-class students. She designed a module where all students had the opportunity to be a role model in a poor-performing school or community centre in a deprived area. The module took the notion of employability further as it helped the students in her class, mainly from disadvantaged backgrounds, to develop skills not often found in other modules, but had the added benefit of potentially helping the young people that the students interacted with, because as Burgess et al. (2017) found, an inspirational talk from a current student increases the chance of an application to university. Joy, saw herself as an agent of change:

'[T]he same people are the teachers, in the judiciary, civil servants etc. We need to be the example of change. Our students need the help we never got.' (Crew, 2020: 103).

Jane, a researcher in Biological Science at a Russell Group institution, would invite speakers from working-class backgrounds such as local people in professional employment so that students could see people like 'us' in top jobs (Crew, 2020, p.105). These examples of using knowledge to challenge inequality is what Yosso (2005) refers to as being resistant capital.

\section{Innovative Teaching Approaches}

Eighty per cent (n.72) of respondents outlined examples of how their social biography gave them pedagogical advantages. An edited collection by Shepard et al. (1998) reminds us that one's working-class heritage can positively impact one's pedagogy. Daniels (1998) refers to making poetry accessible to working-class students by including poems on themes that his students can relate to i.e about school, getting in trouble and relationships (p.3). My own respondents often drew upon the work of Paulo Freire (1970) as Freire supported 'co-creation', an approach where teachers and students are learners in joint inquiry (Freire 1993). Research by Willis and Gregory (2016) found that co-creation was perceived by students as being an innovative pedagogical approach, commenting that 'it didn't feel like the usual chalk and talk'. Methods of co-creation among my own respondents included course redesign. For instance, Amy, a teaching fellow in English at a Russell Group institution, used student 'consultants' to provide advice on how to embed employability throughout her programme. While Emma, a teaching assistant in Health Studies at a post 1992 institution module, included students in her assessment design. Emma and her students critiqued the UK governments advice to eat five fruit and vegetables a day and from this discussion, the idea for an assignment developed, one that asked students to spend only $£ 1$ per day, for a week, while on the university grounds, and then report back on their experience of trying to eat healthily. She used this assignment to highlight how many people were already managing on a low income.

My respondents tended to avoid using essays and exams as a mode of assessment and, instead, created atypical assignments. Jack, a teaching associate in Mathematics at an Oxbridge institution, had students working in groups to design a website with guides to GCSE ${ }^{12}$ maths problems. While Theo ${ }^{13}$ and Jeremy ${ }^{14}$ co-designed, with students, social media campaigns to raise awareness of specific issues. Zandy (1995) remarks that many WCA have 'pedagogical gifts forged from lived experience' (p. 592). In an assessment set by Theo, a Politics research fellow at a Russell Group institution, he drew upon stories from his relatives who were part of

\footnotetext{
${ }^{12}$ The General Certificate of Secondary Education (GCSE) is an academic qualification in a particular subject, taken in England, Wales, and Northern Ireland.

13 Theo, a Politics research fellow at a Russel Group Institution

${ }^{14}$ Jeremy, a postdoctoral researcher in Geography at a traditional institution
} 
the 'Windrush generation'15 and gave students the assignment of keeping a diary of a fictional character travelling to England on Empire Windrush. In his attempt to make the historically invisible, visible, Brandon, a lecturer in Political Studies with a disability, referred to his own experiences as a way of helping students to understand how the concept of disability has changed during specific historical periods. While Pat, a professor in Biological Sciences at an Oxbridge institution who once struggled to summarise research, set her students the weekly task of producing one-minute papers. Alongside this, most of these academics had a keen desire to teach in a clear manner, explaining concepts in accessible ways [Samantha, a $\mathrm{PhD}$ student in Geography at a Post 1992 institution].

Unpacking the interview data also revealed that interviewees engaged with their students from a strengths-based perspective. Talking about his own institution, but echoed by many respondents, Jeremy, a postdoctoral researcher in Geography at a traditional institution noted that, rather than being in deficit, many of my best students are from disadvantaged communities. Over half of my cohort (n.51) gave examples of 'teaching from a strengths-based perspective'. This approach links well with 'funds of knowledge' (FoK), an anthropological term which refers to the resources and knowledge essential for individuals to function appropriately in his/her community (Hogg 2011, p. 667). FoK include painting, construction, cooking, 'making things', household management, knowledge about computer games and accumulated life experiences (Hogg, 2011). Among my own interviewees, Mark, a lecturer in Engineering found that some of the working-class students he encountered had an innate understanding of how objects worked e.g. being able to repair old appliances, reflecting that this was a skillset useful for an engineering degree. While Brandon a lecturer in Political Studies noted that he was able to discuss welfare benefits with his students more effectively due to the FoK the mature students in his class possessed. 'Dark funds of knowledge' e.g. domestic violence, mental illness etc, can often be rich assets for learning (Zipin, 2009, p. 325). Victoria, a lecturer in English Literature from a post 1992 institution, inspired by Cash Carraway's 2019 book, Skint Estate, created an assignment where students kept a diary for two months, recording any personal difficulties they faced before reflecting on related literature and support systems. Overall, respondents felt that students enjoyed this type of assessment as it was academic writing that recognises their lived experience.

\section{Conclusion}

This UK wide study provides the most comprehensive picture we have of UK academics from working class backgrounds to date. The research supports existing literature as many respondents noted their differences in comparison to their middle-class counterparts, in relation to their accent, style of dress or even sense of humour. Furthermore, like Warnock (2016), examples of microaggressions were found, with female, and respondents of colour experiencing them most frequently although my study noted that men faced more overt microaggressions. This study also contributes to the literature by highlighting that WCA have assets that they bring to the academy, such as their approach to student support and teaching. In relation to teaching, this study demonstrated the innovative and creative pedagogy that WCA brought to university settings. Furthermore, they demonstrated forms of capital such as linguistic capital (explaining concepts without reverting to academic language); resistance capital (were agents of change) and navigational capital (provided IAG in informal community

\footnotetext{
15 The 'Windrush' generation are those who arrived in the UK from Caribbean countries between 1948 and 1973 to work in sectors affected by Britain's post-war labour shortage. The name 'Windrush' derives from the 'HMT Empire Windrush' ship which brought one of the first large groups of Caribbean people to the UK in 1948. See https://www.jcwi.org.uk/windrush-scandal-explained
} 
settings). This study on WCA demonstrates that it is important that the assets WCA bring to academia are recognised ${ }^{16}$. Thus, if you are a WCA, consider your teaching and research practice and reflect on what is your cultural wealth. What do you bring to academia? What are your funds of knowledge?

\section{Recommendations for further research}

There is scope to conduct a study that does not rely on the researchers social networks. Alongside this, quantitative research that considers the numbers of WCA, would be useful, as well as a study that considers how/if these numbers have been affected due to the introduction of fees in the UK in recent years. Further consideration is also needed in relation as to how class intersects with gender, ethnicity, disability etc in this field.

\section{Concluding Remarks}

I close with a reminder from Shukie (2020) and others about working-class people in academia:

'Working class is not an accent to be lost ... a savagery to be civilised ... a roughness to be polished ... [nor] a background to be assimilated' (para. 24). 'We', working class academics, sparkle with pedagogical gifts (Crew, 2020) and represent a bridge between ' 'educated' middle-class life to the 'real' world' (Greenwald and Grant 1999: 28). 'Working class is achievement.. a space of philosophy, art, science. Working class are active creators of knowledge not the passive subject of other peoples'.' Working Class as Academics (Shukie (2020, para. 24).

\section{Author Bio}

Teresa Crew is a Senior Lecturer in Social Policy at Bangor University. She is the author of Higher Education and Working-Class Academics. Precarity and Diversity in Academia, published in 2020 with Palgrave Macmillan. In 2019 she became a Senior Fellow of the Higher Education Academy (SFHEA). In 2018 Dr Crew was the winner of the Policy Press Outstanding Teaching Award by the Social Policy Association. Alongside this, she was awarded a Bangor University Teaching Fellowship. Her PhD, which was funded by the Economic and Social Research Council, was completed in 2014. The thesis focused on graduate inequalities in relation to class, gender and place. Her research interests are related to class and its intersections.

\footnotetext{
${ }^{16}$ There are societies and associations relating to working class academics in the UK. I highly recommend Working-Class Academics (WCA) who advocate for students and faculty of poverty and working-class origins (For more details: https://wcstudiesassociation.wordpress.com/working-class-academics-section ). I was fortunate to attend and speak at their inaugural conference and the collective joy of being able to speak without fear of critique of one's regional accent, or supposed lack of cultural capital, was palpable.

The Association of Working Class Academics is an international collection of academics who have formed the association in order to support the working class in academia. For more details https://workingclassacademics.com
} 


\section{Bibliography}

Ashley, L., J. Duberley, H. Sommerlad, \& D. Scholarios (2015). A qualitative evaluation of non-educational barriers to the elite professions. Social Mobility and Child Poverty Commission.https://dera.ioe.ac.uk/23163/1/A_qualitative_evaluation_of_noneducatio nal_barriers to the elite_professions.pdf

Atherton, G., Mazhari, T. (2019). Working class heroes - understanding access to higher education for white students from lower socio-economic backgrounds. A National Education Opportunities Network (NEON) report.

https://www.educationopportunities.co.uk/wp-content/uploads/Working-ClassHeroes-Understanding-access-to-Higher-Education-for-white-students-from-lowersocio-economic-backgrounds.pdf

Attfield, S. (2007). The Working-Class Experience in Contemporary Australian Poetry. PhD Thesis. University of Technology, Sydney. https://opus.lib.uts.edu.au/handle/10453/20148

Azizinezhad, M., Hashemi, M. (2011). Humour: a pedagogical tool for language learners. Procedia - Social and Behavioural Sciences, 30, 2093-2098. https://doi.org/10.1016/j.sbspro.2011.10.407

Bourdieu, P. (1984). Distinction: a social critique of the judgement of taste. Routledge.

Bourdieu, P. (1986). The forms of capital. In J. Richardson (Ed.), Handbook of theory and research for the sociology of education. Greenwood.

Bourdieu, P. (2001). Masculine domination. Polity Press

Bridges, L. (2017). Transition to the academy: the influence of working-class culture for first-generation students. University of Massachusetts Graduate Doctoral Dissertations. 318. https://scholarworks.umb.edu/cgi/viewcontent.cgi?article=1317\&context=doctoral_di ssertations

Burgess, S., Greaves, E., Murphy R. (2017). Evaluation of teachers' pay reform: technical appendix. DfE Research Report.

https://core.ac.uk/download/pdf/144579192.pdf

Campaign for Science and Engineering (CaSE). (2014). Improving Diversity in STEM. CaSE.

https://www.sciencecampaign.org.uk/resource/ImprovingDiversityinSTEM2014.html

Case, K. (2017). Insider without: journey across the working-class academic arc. Journal of Working-Class Studies, 2(2), 16-35. https://doi.org/10.13001/jwcs.v2i2.6081

Chartered Institute for Personnel Development (CIPD). (2006) Diversity in business: how much progress have employers made?

https://www.cipd.co.uk/NR/rdonlyres/53CF3D4F2215-4DA6-AEBFC67C99A67F1C/0/diversbus0606.pdf

Collins, P. (1986). 'Learning from the outsider within: The sociological significance of Black Feminist thought, Social Problems, vol. 33, no. 6. pp 14-32.

Coogan. R. (2019). A working-class accent in academia is a blessing and a curse. Times Higher Education. https://www.timeshighereducation.com/opinion/working-classaccent-academia-blessing-and-curse

Crenshaw, K. (1989). Demarginalizing the intersection of race and sex: a black feminist critique of antidiscrimination doctrine, feminist theory and antiracist politics. University of Chicago Legal Forum.

Crew, T. (2020). Higher education and working-class academics. precarity and diversity in academia. Palgrave Macmillan. 
Daniels, J. (1998). Class and the classroom: going to work. In A. Shepard , J. McMillan., \& G. Tate (Eds.), Coming to class: pedagogy and the social class of teachers. Boynton Cook Publishers.

Dews, B., \& Law, L. (1995). This fine place so far from home: voices of academics from the working class. Temple University Press.

Dovidio, J. (2001). On the nature of contemporary prejudice: the third wave. Journal of Social Issues, 57(4), 829-849. https://doi.org/10.1111/0022-4537.00244

Faulkner, C. (1998). Truth and the working class in the working classroom. In A. Shepard., J. McMillan., and G. Tate. (Eds). Coming to class: pedagogy and the social class of teachers. Boynton Cook Publishers.

Freire, P. (1970). Pedagogy of the oppressed. Herder and Herder.

Friedman, S., Laurison, D. (2019). The class ceiling: why it pays to be privileged. Bristol University Press.

Gabriel, D., Tate, S. (2017). Inside the ivory tower: narratives of women of colour surviving and thriving in British academia. Trentham Books.

Gelinas L., Pierce R., Winkler S., Cohen I.G., Lynch H.F., Bierer B.E. (2017). Using social media as a research recruitment tool: ethical issues and recommendations. Am J Bioeth. 17(3), 3-14. https://doi.org/10.1080/15265161.2016.1276644

Gilde, J., Volman, M. (2021) Finding and using students' funds of knowledge and identity in superdiverse primary schools: a collaborative action research project. Cambridge Journal of Education. 51(6). https://doi.org/10.1080/0305764X.2021.1906845

Hastie, A. (2021). Class act: reflections on a working-class academic sense of self as a Graduate Teaching Assistant. Postgraduate Pedagogies, 1(1), 27-46. https://journals.studentengagement.org.uk/index.php/gtateach/article/view/1055

Hearn, J. (2015). Men of the world: genders, globalizations, transnational times. Sage Publications.

Hoggart, R. (1989). Introduction. In, G. Orwell. The Road to Wigan Pier. Secker \& Warburg.

Hogg, L. (2011). Funds of knowledge: an investigation of coherence within the literature. Teaching and Teacher Education, 27(3), 666-677. https://doi.org/10.1016/j.tate.2010.11.005

James, D. (2004). A need for humor in online courses. College Teaching, 52(3), 93-120. https://doi.org/10.3200/CTCH.52.3.93-120

Jenkins, R. (2000). Categorization: identity, social process and epistemology. Current Sociology, 48(3), 7-25. https://doi.org/10.1177/0011392100048003003

Jones, O. (2011). Chavs: the demonization of the working class. Verso.

Lawler S. (2005). Disgusted subjects: the making of middle-class identities. The Sociological Review. 53(3):429-446. https://doi.org/10.1111/j.1467-954X.2005.00560.x

Leathwood, C., Read, B. (2020). Short-term, Short-changed? A temporal perspective on the implications of academic casualisation for teaching in higher education. Teaching in Higher Education. 1-16. https://doi.org/10.1080/13562517.2020.1742681

LeCourt, D., Napoleone, A. (2011) Teachers with(out) class: transgressing academic social space through working-class performances. Pedagogy. 11 (1): 81-108. https://doi.org/10.1215/15314200-2010-018

Lilienfeld S. (2017). Microaggressions: strong claims, inadequate evidence. Perspectives on Psychological Science. 12(1):138-169. https://doi.org/10.1177/1745691616659391

Lubrano, A. (2005). Limbo: blue-collar roots, white-collar Dreams. Wiley.

Mahony, P., Zmroczek, C. (1997). Class matters : 'working-class' women's perspectives on social class. Taylor and Francis.

Mazurek, R. (2009). Work and class in the Box Store University: autobiographies of 
working-class Academics.' College Literature, vol. 36, no. 4, pp. 147-

178. https://doi:10.1353/lit.0.0084

McKenzie, L. (2015, October 8). Who would be a working-class woman in academia? Times Higher Education.

https://www.timeshighereducation.com/blog/lisa-mckenzie-who-would-be-workingclass-woman-academia

Michell, D., Wilson, J. Z., Archer, V. (Eds.). (2015). Bread and roses: voices of Australian academics from the working class. Sense Publishers.

Morad M. (2012). Book review of Chavs: the demonization of the working class by Owen Jones. Local Economy. 27(5-6):682-684. https://doi.org/10.1177/0269094212446296

National Institute for Health Research (2020) Improving inclusion of under-served groups in clinical research: Guidance from the NIHR INCLUDE project. National Institute for Health Research. www.nihr.ac.uk/documents/improving-inclusion-of-under-servedgroups-in-clinical-research-guidance-from-include-project/25435 accessed 21st October 2021].

Navarro, Z. (2006). In search of cultural interpretation of power. IDS Bulletin, 37(6), 11-22. https://opendocs.ids.ac.uk/opendocs/handle/20.500.12413/8355

Pierce, C. (1970). Offensive mechanisms. In F. Barbour (Ed.), The Black seventies. Porter Sargent Publishers.

Rollock, N. (2019). Staying power: the Career experiences and strategies of UK Black female professors. Universities and College Union. https://www.ucu.org.uk/media/10075/StayingPower/pdf/UCU_Rollock_February_2019.pdf

Ruths, D., and Jurgen, P. (2014). Social media for large studies of behavior. Science, 10631064.

Ryan, J., Sackrey, C. (1984). Strangers in paradise: academics from the working class. South End Press.

Shukie, P. (2020). Why a working-class academics conference? Because we need a celebration, not an apology. The Peoples Powerhouse.

https://peoplespowerhouse.org.uk/blogs/blog/collaboration/academics

Skeggs, B. (1997). Formations of class and gender: becoming respectable. Sage Publications.

Stiles, S. (201). Blue-collar advantage: how working-class academics can bring us together. Times Higher Education, April $25^{\text {th }} 2017$. https://www.timeshighereducation.com/blog/blue-collar-advantage-how-workingclass-academics-can-bring-us-together

Sue, D., Capodilupo, C., Torino, G., Bucceri, J., Holder, A., Nadal, K., Esquilin, M. (2007). Racial microaggressions in everyday life: implications for clinical practice. American Psychologist, 62(4), 271. https://doi.org/10.1037/0003-066X.62.4.271

Sue, D. (2010). Microaggressions in everyday life: race, gender, and sexual orientation. Wiley.

Warnock, D. (2016). Paradise lost? patterns and precarity in working-class academic narratives. Journal of Working-Class Studies, 1(1), 28-44. https://doi.org/10.13001/jwcs.v1i1.6013

Weale, S. (2019, May 23). Higher education staff suffer 'epidemic' of poor mental health. The Guardian. https://www.theguardian.com/education/2019/may/23/higher-education-staff-sufferepidemic-of-poor-mental-health

Williams, Z. (2013, January 9). Skivers v strivers: the argument that pollutes people's minds. The Guardian. 
https://www.theguardian.com/politics/2013/jan/09/skivers-v-strivers-argumentpollutes

Willis, P., Gregory, A. (2016). Making the road while walking: cocreation, teaching excellence and university leadership. Leadership Foundation for Higher Education. https://eprints.leedsbeckett.ac.uk/id/eprint/3329/

Yosso, T. (2005). Whose culture has capital? a critical race theory discussion of community cultural wealth. Race, Ethnicity and Education, 8(1), 69-91. https://doi.org/10.1080/1361332052000341006

Zandy, J. (1995). What we hold in common: an introduction to working-class studies. Feminist Press

Zheng, R. (2018). Precarity is a feminist issue: gender and contingent labor in the academy. Hypatia, 33 (2):235-55. http://doi:10.1111/hypa.12401

Zipin, L. (2009) Dark funds of knowledge, deep funds of pedagogy: exploring boundaries between lifeworlds and schools. Discourse: Studies in the Cultural Politics of Education, 30(3), 317-331. https://doi.org/10.1080/01596300903037044 